UDC 613.6.02

DOI: $10.21668 /$ health.risk/2021.2.08.eng

Research article

\title{
RISKS RELATED TO COGNITIVE DISORDERS DEVELOPMENT IN WORKERS WITH DIFFERENT WORK EXPERIENCE EMPLOYED AT AN OIL EXTRACTING FACILITY
}

\author{
M.A. Savinkov ${ }^{1}$, O.Yu. Ustinova ${ }^{1,2}$, A.E. Nosov ${ }^{1}$, Yu.A. Ivashova ${ }^{1}$, V.G. Kostarev ${ }^{3}$ \\ ${ }^{1}$ Federal Scientific Center for Medical and Preventive Health Risk Management Technologies, 82 Monastyrskaya \\ Str., Perm, 614045, Russian Federation \\ ${ }^{2}$ Perm State University, 15 Bukireva Str., Perm, 614990, Russian Federation \\ ${ }^{3}$ Federal Service for Surveillance over Consumer Rights protection and Human Well-being, Perm regional office, \\ 50 Kuibysheva Str., Perm, 614016, Russian Federation
}

Our research goal was to examine cognitive functions parameters in dynamics among workers employed at an oil extracting facility depending on their work experience under exposure to adverse occupational factors.

We estimated cognitive functions in 292 oil and gas extraction operators who were exposed to adverse occupational factors (aromatic hydrocarbons, hydrogen sulphide, occupational noise, labor hardness, and adverse microclimate). The reference group consisted of 65 administrative workers employed at the same enterprise. All the examined people were males aged 20-65; they were divided into several sub-groups depending on their work experience: the $1^{\text {st }}$ subgroup, work experience shorter than 10 years; the $2^{\text {nd }}$ subgroup, 10-20 years; the $3^{\text {rd }}$ sub-group, longer than 20 years. All the subgroups were comparable as per average age $(p>0.05)$. Nervous systems diseases that caused cognitive deficiency were a criterion for exclusion from the research groups. We performed neural-psychological examination using «NS-Psychotest» computer complex ("Concept exclusion», short term memory tests for pictures and figures, square number test). To analyze dependence between cognitive disorders and work experience duration in the test and reference groups, we calculated relative risk and its $95 \%$ confidence interval (results are given as RR (95\% CI)). We also performed one-factor linear regression analysis of dependence on work experience separately for each parameter of examined cognitive functions.

Oil and gas extraction operators tended to have 1.3-1.6 times lower cognitive flexibility, picture and number memory, and attention than people who worked under permissible working conditions at their work places. Oil and gas extraction operators with their work experience being equal or exceeding 10 years ran more than 5 times higher risk of cognitive disorders; memory, attention, and analytical activity parameters were lower among them 2-3 times more frequently. Basing on relative risk calculation and one-factor linear regression analysis, we established a correlation between cognitive disorders development and work experience duration. Periodical medical examinations provided for oil and gas extraction operators should include neural-psychological tests that assess memory, attention, and cognitive flexibility since it will allow diagnosing cognitive dysfunction at an early (pre-dementia) stage and revealing people with its minimal signs for further profound examination, prevention activities, and occupational examination.

Key words: cognitive functions, number and picture memory, attention, cognitive flexibility, cognitive deficiency, neuralpsychological testing, oil extracting industry, occupationally induced pathology, adverse occupational factors, work experience.

The Economic Safety Strategy approved pectancy and extended period of employment in the Russian Federation for a period up to (in particular, for workers who have to work 2030 lists an issue related to longer life ex- under adverse and hazardous working condi-

(c) Savinkov M.A., Ustinova O.Yu., Nosov A.E., Ivashova Yu.A., Kostarev V.G., 2021

Maksim A. Savinkov - Functional diagnostics expert (e-mail: msavinkov@yandex.ru; tel.: +7 (342) 237-25-34; ORCID: https://orcid.org/0000-0001-5776-8182).

Olga Yu. Ustinova - Doctor of Medical Sciences, Associate Professor, Head of Human Ecology and Life Safety Department (e-mail: ustinova@fcrisk.ru; tel.: +7 (342) 236-32-64; ORCID: http://orcid.org/0000-0002-9916-5491).

Aleksandr E. Nosov - Candidate of Medical Sciences, Head of In-patient Clinic (Therapeutic Work-related Pathology Department) (e-mail: nosov@fcrisk.ru; tel.: +7 (342) 236-87-80; ORCID: https://orcid.org/0000-0003-0539-569X).

Yuliya A. Ivashova - Sonologist (e-mail: nemo@fcrisk.ru; tel.: +7 (342) 237-25-34; ORCID: http:// orcid.org/0000-0002-5671-3953).

Vitalii G. Kostarev - Candidate of Medical Sciences, Chief State Sanitary inspector in Perm region, Head of Rospotrebnadzor office in Perm region (e-mail: urpn@59.rospotrebnadzor.ru; tel.: +7 (342) 239-35-63; ORCID: https://orcid.org/0000-0001-5135-8385). 
tions) among priority tasks the state is to solve ${ }^{1}$.

Cognitive disorders among employable population are a vital task that is to be solved by contemporary medicine. Sub-clinical (predementia) cognitive disorders that occur among employable population become apparent via memory disorder, poorer ability to focus one's attention, and greater fatigue at the end of a working shift $[1,2]$. Apparent cognitive disorders disrupt every day and occupational activities and result in lower life quality. It has been shown that as a person grows older, cognitive disorders become more and more frequent with their frequency growing progressively and reaching $20 \%$ among people aged 60-69 [3, 4]. Adequate functioning and plasticity of synapses in the central nervous system (CNS) is among factors that determine cognitive and neuroplastic potential and support learning processes and memory $[5,6]$. A substantial loss of these neuronal structures caused by ageing, various diseases, or exposure to toxic agents can has such clinical manifestation as cognitive disorders syndrome [7-9].

As per data provided by G.V. Timasheva et al., working under adverse working conditions is a risk factor that may cause cognitive disorders [10]. It was established that toxic effects might be produced on a body by a wide range of chemicals under certain conditions. These conditions include a dose, exposure duration, as well as a way through which a chemical is introduced into a body [11]. At present workers employed at oil extracting enterprises are exposed to such adverse chemicals as sulfur dioxide, carbon oxide, and aromatic hydrocarbons [12]. Chronic exposure to chemical factors in low doses that is typical for oil extraction causes disorders in the nervous system $^{2}$ [13]; these disorders are further aggravated due to impacts exerted by additional occupational factors (occupational noise, labor hardness and intensity) $)^{3}$ [14-16].
Workers employed at an oil extracting enterprise are exposed to several adverse occupational factors at their workplaces (chemical factors and noise) and these factors can be seen as risk factors that might cause cognitive disorders. At the same time, so far there hasn't been sufficient research on parameters of cognitive functions taken in dynamics that is related to work experience duration. This issue becomes especially vital since technological processes are getting faster and more complicated and it makes greater demands of workers to be precise in their actions and to be able to make quick decisions when performing production operations. Any mistake can result in an emergency including those when people's lives are threatened [14].

Our research goal was to examine cognitive function parameters among workers employed at an oil extracting enterprise and to develop feasible criteria for early diagnostic of functional disorders in the brain. These parameters were taken in dynamics depending on duration of work experience under exposure to adverse occupational factors.

Data and methods. Our examined sampling was made up of 357 workers employed at an oil-extracting enterprise; 292 were oil and gas extraction operators (the test group) and 65 administrative workers (the reference group). Workers in both groups were males, aged 20-65, and their working experience at the examined enterprise was longer than 1 year. Both groups were divided into three subgroups according to duration of their working experience; subgroup I included workers with their working experience being shorter than 10 years; subgroup II, 10-20 years; subgroup III, longer than 20 years. All subgroups were comparable in terms of average age and working experience $(p>0.05)$. Results obtained via special assessment of working conditions (hereinafter SAWC) allowed establishing that all the

\footnotetext{
${ }^{1}$ On The Economic Safety Strategy in the Russian Federation for a period up to 2030: The RF President Order issued on May 13, 2017 No. 208. Garant. Information and legal portal. Available at: https://www.garant.ru/products/ipo/ prime/doc/71572608/ (May 13, 2021).

${ }^{2}$ Occupational pathology: the national guide. In: N.F. Izmerov ed. Moscow, GEOTAR-media Publ., 2011, 784 p.

${ }^{3}$ Adverse chemicals. Hydrocarbons, halogen-derivatives of hydrocarbons: reference book. In: V.A. Filov ed. Leningrad, Chemistry Publ., 1990, 592 p.
} 
workers from the test group had to work under "adverse" working conditions with 3.1-3.2 hazard category. Technological operations involved chemicals emissions into working area air with prevailing saturated aliphatic hydrocarbons $\mathrm{C} 1-10$ (recalculated as per C) in concentrations that didn't' exceed hygienic standards and dihydrosulfate mixed with hydrocarbons C1-5 (hydrogen sulfate) in concentrations that were up to 1.2 times higher than MPC $\left(10 \mathrm{mg} / \mathrm{m}^{3}\right)$. Noise at working places was 1.1 times higher than maximum permissible level for workers from the test group and reached $87-88 \mathrm{~dB}$. Working conditions for workers from the reference group corresponded to hazard category 2 (permissible).

Our research program included analysis of working conditions as per SAWC results and assessment of workers' cognitive functions as per results obtained via neuralpsychological examination that was performed with "NS-Psychotest" computer complex ("Neurosoft", Russia, SN 0384UX). The research involved estimating such intellectual operations as classification and analysis via "Concepts exclusion" test; image memory was estimated with "Image memory" test; number memory, "Number memory" test; and attention, "Number square" test ${ }^{4}$.

All the data were accumulated, adjusted, processed and analyzed with IBMSPSS Statistics 22 software for statistical analysis. Analysis was performed with non-parametric statistic techniques. Data obtained for different groups are given in tables as median values $(\mathrm{Me})$ and $25-75$ percentiles. Quantitative attributes were compared as per Mann - Whitney test. Differences were considered authentic at $p<0.05^{5}$. Qualitative attributes were assessed with Fischer's z-test.

To analyze dependence between cognitive disorders and duration of working experience in the test and reference group, we calculated relative risk and its $95 \%$ confidence interval (the results are given as $(95 \% C I))$; also, we performed one-factor linear regression analysis separately for each parameter of examined cognitive functions. This analysis allowed estimating parameters of a model given as per the following formula (1):

$$
y=b_{0}+b_{1} \cdot x+\varepsilon,
$$

where

$y$ is resulting quantitative attribute;

$b_{1}$ is model coefficient;

$b_{0}$ is model constant;

$\varepsilon$ is random error in the model;

$x$ is working experience under exposure to a set of adverse working conditions (the test group) or without such exposure at a workplace (the reference group).

To assess quality of the linear function, we calculated F-criterion and a square of linear correlation coefficient $R^{2}$ (determination coefficient).

The present research work was accomplished in conformity with ICHGCP Rules and with adherence to ethical standards stipulated by Helsinki Declaration (edited in 2008) and the RF National Standard GOST-R 52379-2005 "Good clinical practice" (ICH E6 GCP $)^{6}$. The research program was approved by the Ethical Committee of the Federal Scientific Center for Medical and Preventive Health Risk Management Technologies (The meeting report No. 55 dated December 20, 2018). All the workers were informed about research goals and gave their voluntary informed consent to take part in the research.

Results and discussion. Having assessed abilities to classify and analyze among workers from all the subgroups, we revealed authentic differences between the groups, namely fewer correct answers given by workers from the test group against those from the reference one $(13(10 ; 15)$ against $14(13 ; 15), p=0.003)$. A share of people with low cognitive flexibility was 5 times higher in the test group than in the reference one $(25.2 \%$ and $4.5 \%$, $p=0.003)($ Table 1$)$.

\footnotetext{
${ }^{4}$ Shapar' V.B., Timchenko A.V., Shvydchenko V.N. SH23 Practical psychology. Instruments. Rostov-na-Donu: "Phoenix" publishers, 2002, $688 \mathrm{p}$.

${ }^{5}$ Glants S. Medical and biological statistics. Moscow, Praktika Publ., 1998, 462 p.

${ }^{6}$ GOST-R 52379-2005. Good clinical practice in the RF. Moscow, Standartinform Publ., 2005, 39 p.
} 
Comparative analysis of data obtained via "Concepts exclusion" tests among all the examined workers

\begin{tabular}{|l|c|c|c|}
\hline \multicolumn{1}{|c|}{ Data obtained via "Concepts exclusion" test } & $\begin{array}{c}\text { Test group } \\
n=210\end{array}$ & $\begin{array}{c}\text { Reference group } \\
n=44\end{array}$ & $\begin{array}{c}\text { Validity of differences } \\
\text { between groups, } \\
p<0.05\end{array}$ \\
\hline Correct answers, number & $13(10 ; 15)$ & $14(13 ; 15)$ & 0.003 \\
\hline \multicolumn{2}{|c|}{ Frequency of detected cognitive flexibility, \% } \\
\hline Low cognitive flexibility, 1-3 scores & 25.2 & 4.5 & 0.002 \\
\hline Average cognitive flexibility, 4-7 scores & 61.0 & 75.0 & 0.08 \\
\hline High cognitive flexibility, 8-9 scores & 13.8 & 20.5 & 0.26 \\
\hline
\end{tabular}

Table 2

Relative risk of cognitive disorders among workers employed at an oil-extracting enterprise as per data obtained via neural-psychological testing

\begin{tabular}{|l|c|c|c|}
\hline \multicolumn{1}{|c|}{ Tests } & $\begin{array}{c}\text { Test group } \\
n=209\end{array}$ & $\begin{array}{c}\text { Reference group } \\
n=44\end{array}$ & $\begin{array}{c}R R \\
(C I 95 \%)\end{array}$ \\
\hline "Concepts exclusion" & $25.2 \%$ & $4.5 \%$ & $\begin{array}{c}R R=5.55 ; 95 \% \\
C I=1.4-21.9\end{array}$ \\
\hline "Number memory" & $52.9 \%$ & $34.1 \%$ & $\begin{array}{c}R R=1.6 ; 95 \% \\
C I=1.0-2.4\end{array}$ \\
\hline "Number square" & $19.3 \%$ & $12.1 \%$ & $\begin{array}{c}R R=1.59 .95 \% \\
C I=0.60-4.20\end{array}$ \\
\hline
\end{tabular}

Relative risk that low cognitive flexibility might occur was 5.6 times higher in the test group than in the reference one $(R R=5.55$; $95 \% C I=1.4-21.9$ ) (Table 2).

$19 \%$ workers from the test group, subgroup I, had low cognitive flexibility; and there were no such workers in the same subgroup from the reference group $(p=0.03)$. Having analyzed data obtained via "Concepts exclusion" test, we revealed authentically fewer correct answers among workers from the test group, subgroup II, against the same subgroup in the reference group, $(13(15 ; 12)$ against $15(14 ; 16), p=0.03) .21 .3 \%$ workers from the test group, subgroup II, had low cognitive flexibility and it was 3.2 times higher than in the same subgroup in the reference group where it was equal to $6.6 \%(R R=3.2$; $95 \% C I=0.45-22.55)$; high cognitive flexibility was 1.5 times less frequent $(18.8 \%$ in the test group, subgroup II, against $26.6 \%$ in the reference group, subgroup II, $p=0.45$ ). "Concepts exclusion" test revealed authentically fewer correct answers among workers from the test group, subgroup III, against their counterparts from the reference group, subgroup III $(11(7 ; 14)$ against $14(12 ; 15), p=0.04)$.
$42.9 \%$ workers from the test group, subgroup III, had low cognitive flexibility against $11.1 \%$ in the same subgroup in the reference group $(R R=3.9 ; 95 \% C I=0.59-25.18)$. Having assessed dynamics related to working experience we noticed that there was an authentic 1.3-time decrease in a number of correct answers given by workers from the test group, subgroup III, against their counterparts from the same group, but subgroup I $(11(7 ; 14)$ against $14(12 ; 15)$, $p=0.001)$ whereas these attributes were quite similar in the reference group $(14(13 ; 15.5)$ against $14(12 ; 15), p=0.64)$ (Table 3$)$.

Image memory was assessed with "Image memory" test; the assessment revealed fewer correct answers in the test group than in the reference one $(8(6 ; 10)$ against $10(7 ; 12)$, $p=0.01)$, and capacity of image memory was by $13 \%$ lower in the test group than in the reference one $(43.8 \%$ against $56.3 \%, p=0.01)$ (Table 4).

Having compared data obtained for subgroups II in both groups, we also revealed fewer correct answers in the test group $(9(7 ; 10)$ against $11(9 ; 13), p=0.02)$; besides, median value of image memory capacity turned out to be 1.4 times lower in the test group, subgroup II, 
Table 3

Comparative analysis of data obtained via "Concepts exclusion" test among workers with different working experience

\begin{tabular}{|l|c|c|c|c|c|c|c|c|c|c|}
\hline $\begin{array}{c}\text { "Concepts } \\
\text { exclusion" } \\
\text { test data }\end{array}$ & $\begin{array}{c}\text { Test group, } \\
\text { subgroup I } \\
n=100\end{array}$ & $\begin{array}{c}\text { Test group, } \\
\text { subgroup II } \\
n=61\end{array}$ & $\begin{array}{c}\text { Test group, } \\
\text { subgroup III } \\
n=49\end{array}$ & $\begin{array}{c}\text { Ref.group, } \\
\text { subgroup I } \\
n=20\end{array}$ & $\begin{array}{c}\text { Ref.group, } \\
\text { subgroup II } \\
n=15\end{array}$ & $\begin{array}{c}\text { Ref.group, } \\
\text { subgroup III } \\
n=20\end{array}$ & $p^{1}$ & $p^{2}$ & $p^{3}$ \\
\hline $\begin{array}{l}\text { Correct answers, } \\
\text { number }\end{array}$ & $14(12 ; 15)$ & $13(12 ; 15)$ & $11(7 ; 14)$ & $14(13 ; 15.5)$ & $15(14 ; 16)$ & $14(12 ; 15)$ & 0.32 & 0.03 & 0.04 \\
\hline \multicolumn{7}{|c|}{ Frequency of different cognitive flexibility, \% } \\
\hline $\begin{array}{l}\text { Low cognitive } \\
\text { flexibility, } \\
\text { 1-3 scores }\end{array}$ & 19 & 21.3 & 42.9 & 0 & 6.6 & 11.1 & 0.03 & 0.19 & 0.07 \\
\hline $\begin{array}{l}\text { Average cognitive } \\
\text { flexibility, } \\
\text { 4-7 scores }\end{array}$ & 64 & 60.7 & 55.1 & 75 & 66.7 & 88.9 & 0.34 & 0.67 & 0.06 \\
\hline $\begin{array}{l}\text { High cognitive } \\
\text { flexibility, } \\
8-9 \text { scores }\end{array}$ & 17 & 18.0 & 2.0 & 25 & 26.6 & 0.0 & 0.39 & 0.45 & 0.67 \\
\hline
\end{tabular}

$\mathrm{N}$ o t e : $p^{1}$ is validity of differences between the test group, subgroup I, and the reference group, subgroup I; $p^{2}$ is validity of differences between the test group, subgroup II, and the reference group, subgroup II; $p^{3}$ is validity of differences between the test group, subgroup III, and the reference group, subgroup III.

Table 4

Comparative analysis of data obtained via "Image memory" test among all the examined workers

\begin{tabular}{|l|c|c|c|}
\hline \multicolumn{1}{|c|}{ "Image memory" test data } & $\begin{array}{c}\text { The test group } \\
n=209\end{array}$ & $\begin{array}{c}\text { The reference group } \\
n=44\end{array}$ & $\begin{array}{c}\text { Validity of differences } \\
\text { between groups, } p<0.05\end{array}$ \\
\hline Correct answers, number & $8(6 ; 10)$ & $10(7 ; 12)$ & 0.009 \\
\hline Mistakes, number & $1(0 ; 2)$ & $1(0 ; 1)$ & 0.21 \\
\hline Memory capacity, \% & $43.8(25 ; 62.5)$ & $56.3(34.4 ; 71.9)$ & 0.007 \\
\hline \multicolumn{2}{|c|}{ Frequency of accuracy in reproducing images, \% } \\
\hline $\begin{array}{l}\text { Low image reproduction accuracy } \\
\text { from 0 to 5) }\end{array}$ & 21.5 & 15.9 & 0.40 \\
\hline $\begin{array}{l}\text { Standard image reproduction accuracy } \\
\text { (more than 5) }\end{array}$ & 86.9 & 84.1 & 0.40 \\
\hline
\end{tabular}

than in the same subgroup in the reference group (43.8 \% against $62.5 \%, p=0.03)$. We didn't detect any authentic differences between subgroups I and III regarding image memory capacity; however, there was an authentic 1.2-time decrease in a number of correct answers given by workers from the test group, subgroup III, against subgroup I in the same group $(7(4 ; 9)$ against $9(7 ; 11)$, $p=0.001)$. Low image reproduction accuracy was also 3 times more frequent in the test group, subgroup III, than in subgroup I (36.4\% and $13.1 \%, p=0.001)$. There were no authentic differences between subgroups in the reference group (Table 5).

Having assessed number memory as per results obtained via "Number memory" test, we established a statistically significant decrease in a number of correct answers given by workers from the test group than by those from the reference one $(7(6 ; 8)$ and $8(7 ; 9.5)$, $p=0.002)$. Besides, capacity of number memory was by $8.3 \%$ lower in the test group than in the reference one $(50(33.3 ; 66.7)$ and 58.3 $(41.7 ; 75), p=0.03$ ) (Table 6). Low accuracy in reproducing numbers was detected in more than half of workers from the test group and it was 1.6 times higher than in the reference group $(52.9 \%$ against $34.1 \% ; R R=1.6 ; 95 \%$ $C I=1.0-2.4)$ (Table 6).

Comparative analysis of data obtained via this test revealed authentically fewer correct answers given by workers from the test group, subgroup I, against workers from the same 
Table 5

Comparative analysis of data obtained via "Image memory" test among workers with different working experience

\begin{tabular}{|l|c|c|c|c|c|c|c|c|c|}
\hline $\begin{array}{l}\text { "Image memory" } \\
\text { test data }\end{array}$ & $\begin{array}{c}\text { Test group, } \\
\text { subgroup I } \\
n=99\end{array}$ & $\begin{array}{c}\text { Test group, } \\
\text { subgroup II } \\
n=61\end{array}$ & $\begin{array}{c}\text { Test group, } \\
\text { subgroup III } \\
n=66\end{array}$ & $\begin{array}{c}\text { Ref.group, } \\
\text { subgroup I } \\
n=20\end{array}$ & $\begin{array}{c}\text { Ref.group, } \\
\text { subgroup II } \\
n=15\end{array}$ & $\begin{array}{c}\text { Ref.group, } \\
\text { subgroup III } \\
n=9\end{array}$ & $p^{1}$ & $p^{2}$ & $p^{3}$ \\
\hline $\begin{array}{l}\text { Correct answers, } \\
\text { number }\end{array}$ & $9(7 ; 11)$ & $9(7 ; 10)$ & $7(4 ; 9)$ & $10.5(9 ; 11.5)$ & $11(9 ; 13)$ & $6(5 ; 10)$ & 0.27 & 0.02 & 0.57 \\
\hline Mistakes, number & $1(0 ; 2)$ & $1(0 ; 2)$ & $1(0 ; 3)$ & $1(0 ; 2)$ & $1(0 ; 3)$ & $1(0 ; 1)$ & 0.86 & 0.32 & 0.13 \\
\hline $\begin{array}{l}\text { Memory } \\
\text { capacity, \% }\end{array}$ & $\begin{array}{c}50 \\
(31.3 ; 62.5)\end{array}$ & $\begin{array}{c}43.8 \\
(25 ; 62.5)\end{array}$ & $\begin{array}{c}31.3 \\
(18.8 ; 50)\end{array}$ & $\begin{array}{c}56.3 \\
(40.7 ; 68.8)\end{array}$ & $\begin{array}{c}62.5 \\
(43.8 ; 81.3)\end{array}$ & $\begin{array}{c}31.3 \\
(25 ; 62.5)\end{array}$ & 0.31 & 0.03 & 0.21 \\
\hline \multicolumn{7}{|c|}{ Frequency of accuracy in reproducing images, \% } & & & \\
\hline $\begin{array}{l}\text { Low image repro- } \\
\text { duction accuracy } \\
\text { (from 0 to 5) }\end{array}$ & 13.1 & 13.1 & 36.4 & 10 & 13.3 & 33.3 & 0.7 & 0.98 & 0.86 \\
\hline $\begin{array}{l}\text { Standard image } \\
\text { reproduction accu- } \\
\text { racy (more than 5) }\end{array}$ & 86.9 & 86.9 & 63.6 & 90 & 86.7 & 66.7 & 0.7 & 0.98 & 0.86 \\
\hline
\end{tabular}

$\mathrm{N}$ o t e : $p^{1}$ is validity of differences between the test group, subgroup I, and the reference group, subgroup I; $p^{2}$ is validity of differences between the test group, subgroup II, and the reference group, subgroup II; $p^{3}$ is validity of differences between the test group, subgroup III, and the reference group, subgroup III.

Table 6

Comparative analysis of data obtained via "Number memory" test among all the examined workers

\begin{tabular}{|l|c|c|c|}
\hline \multicolumn{1}{|c|}{ "Number memory" test data } & $\begin{array}{c}\text { Test group } \\
n=210\end{array}$ & $\begin{array}{c}\text { Reference group } \\
n=44\end{array}$ & $\begin{array}{c}\text { Validity of differences } \\
\text { between group, } \\
p<0.05\end{array}$ \\
\hline Correct answers, number & $7(6 ; 8)$ & $8(7 ; 9.5)$ & 0.002 \\
\hline Mistakes, number & $1(0 ; 2)$ & $1(0 ; 2)$ & 0.71 \\
\hline Memory capacity, \% & $50(33.3 ; 66.7)$ & $58.3(41.7 ; 75)$ & 0.03 \\
\hline \multicolumn{2}{|c|}{ Frequency of accuracy in reproducing numbers, \% } \\
\hline $\begin{array}{l}\text { Low accuracy in reproducing numbers } \\
\text { (from 0 to 7) }\end{array}$ & 52.9 & 34.1 & 0.02 \\
\hline
\end{tabular}

subgroup in the reference group $(7(6 ; 8.5)$ and $8(7 ; 10)$ accordingly, $p=0.01)$ and a share of workers with low accuracy in reproducing numbers was 1.4 times higher in the test group, subgroup I $(55.0 \%$ and $40.0 \% ; R R=1.37$; $95 \% C I=0.78-2.42)$. There were no statistically significant differences in "Number memory" test results between subgroups II in the test group and the reference group $(p=0.14-0.65)$; however, a share of workers with low accuracy in reproducing numbers was 1.3 times higher in the test group, subgroup II, than in the same subgroup in the reference group (42.6\% and $33.3 \%$ accordingly; $R R=1.3 ; 95 \% C I=0.6-2.8)$. Test results didn't reveal any statistically significant differences between subgroups III in both examined groups; more than half workers from the test group, subgroup III, had low accuracy in reproducing numbers and it was authentically 2.7 times higher than in the reference group, subgroup III $(61.22 \%$ and $22.2 \%$ accordingly; $R R=2.8 ; 95 \% C I=0.79-9.54)$. Having assessed dynamics related to working experience we detected an authentic decrease in a number of correct answers given by workers from the test group, subgroup III, against subgroup I in the same group $(6(5 ; 8)$ against $7(6 ; 8), p=0.02)$ whereas there were no statistically significant difference revealed in the reference group $(8(8 ; 8)$ against $8(7 ; 10)$, $p=0.49)$ (Table 7). 
Table 7

Comparative analysis of data obtained via "Number memory" test among workers with different working experience

\begin{tabular}{|l|c|c|c|c|c|c|c|c|c|c|}
\hline $\begin{array}{l}\text { "Number memory" } \\
\text { test data }\end{array}$ & $\begin{array}{c}\text { Test group, } \\
\text { subgroup I } \\
n=100\end{array}$ & $\begin{array}{c}\text { Test group, } \\
\text { subgroup II } \\
n=61\end{array}$ & $\begin{array}{c}\text { Test group, } \\
\text { subgroup III } \\
n=49\end{array}$ & $\begin{array}{c}\text { Ref.group, } \\
\text { subgroup I } \\
n=20\end{array}$ & $\begin{array}{c}\text { Ref.group, } \\
\text { subgroup II } \\
n=15\end{array}$ & $\begin{array}{c}\text { Ref.group, } \\
\text { subgroup III } \\
n=9\end{array}$ & $p^{1}$ & $p^{2}$ & $p^{3}$ \\
\hline $\begin{array}{l}\text { Correct answers, } \\
\text { number. }\end{array}$ & $7(6 ; 8.5)$ & $8(7 ; 9)$ & $6(5 ; 8)$ & $8(7 ; 10)$ & $8(7 ; 10)$ & $8(8 ; 8)$ & 0.01 & 0.14 & 0.07 \\
\hline Mistakes, number & $1(0 ; 2)$ & $1(0 ; 2)$ & $1(0 ; 2)$ & $1.5(0.5 ; 2.5)$ & $1(0 ; 2)$ & $1(1 ; 2)$ & 0.52 & 0.65 & 0.56 \\
\hline $\begin{array}{l}\text { Memory } \\
\text { capacity, \% }\end{array}$ & $\begin{array}{c}50 \\
(41.7 ; 66.7)\end{array}$ & $\begin{array}{c}50 \\
(41.7 ; 66.7)\end{array}$ & $\begin{array}{c}41.7 \\
(33.3 ; 58.3)\end{array}$ & $\begin{array}{c}58.3 \\
(37.5 ; 75)\end{array}$ & $\begin{array}{c}58.3 \\
(50 ; 75)\end{array}$ & $\begin{array}{c}50 \\
(41.7 ; 58.3)\end{array}$ & 0.2 & 0.16 & 0.26 \\
\hline $\begin{array}{l}\text { Frequency of accuracy in reproducing numbers, \% } \\
\text { Low accuracy in } \\
\text { reproducing num- } \\
\text { bers (from 0 to 7) }\end{array}$ & 55.0 & 42.6 & 61.2 & 40.0 & 33.3 & 22.2 & 0.22 & 0.51 & 0.03 \\
\hline $\begin{array}{l}\text { Standard accuracy } \\
\text { in reproducing } \\
\text { numbers } \\
\text { (more than 7) }\end{array}$ & 45.0 & 57.4 & 40.9 & 60.0 & 66.7 & 77.8 & 0.22 & 0.51 & 0.03 \\
\hline
\end{tabular}

$\mathrm{N}$ o t e : $p^{1}$ is validity of differences between the test group, subgroup I, and the reference group, subgroup I; $p^{2}$ is validity of differences between the test group, subgroup II, and the reference group, subgroup II; $p^{3}$ is validity of differences between the test group, subgroup III, and the reference group, subgroup III.

Attention was assessed with "Number square" test; the assessment revealed fewer correct answers in all subgroups in the test group against the reference group $(11(7 ; 13)$ and $13(10 ; 14)$ accordingly; $R R=1.59,95 \%$ $C I=0.60-4.20)$ (Tables 2 and 8).

Comparative analysis of data obtained for different subgroups revealed that workers from the test group, subgroup II, gave authentically fewer correct answers $(11(8 ; 12)$ and 13.5 $(10.5 ; 14.5), p=0.02)$ than their counterparts from the same subgroup in the reference group; they also made more mistakes $(7(5 ; 11)$ and $5(2.5 ; 7), p=0.03)$. We didn't detect any statistically significant differences between subgroups I and subgroups III in both examined groups $(p=0.28-0.91)$; however, having assessed dynamics related to working experience, we detected an authentic decrease in a number of correct answers given by workers from the test group, subgroup III, against workers form the same group, but subgroup I $(9(6 ; 11)$ against $12(9 ; 14), p=0.002)$. There were no authentic differences in these attributes between subgroups in the reference group (Table 9).

The next stage in our research involved assessing cognitive state of workers from the examined groups as per a number of test parameters that were lower than the standard level detected in each examined workers employed at an oil-extracting enterprise (Table 10). Our comparative analysis revealed that a share of workers without low parameters as per any test tended to be lower among oil and gas extraction operators, $(R R=0.64(95 \% C I \quad 0.44-0.92)$; also, this share was lower regarding low parameters as per just one test $(R R=0.97(95 \%$ CI 0.66-1.44). However, a relative risk that low results would be obtained in 2 or 3 tests was 2.0-3.0 times higher in this group than in the reference one $(R R=2.05(95 \% C I 0.77-5.45)$ and $R R=2.9$ (95\%CI 0.39-21.8) accordingly). Results that were lower than standard levels as per all 4 tests were revealed in $4.3 \%$ oil and gas extraction operators whereas there were no such results revealed in the reference group. Having analyzed cognitive functions in subgroups I, we revealed that a share of workers without lower results as per any test was a bit lower in the test group $(R R=0.59(95 \% C I$ 0.37-0.92); however, relative risk that lower results would be detected in 1 and 2 tests tended to increase and was $R R=1.12(95 \%$ $C I 0.55-2.26)$ and $R R=2.52$ (95 \% CI 0.65-9.82) accordingly. And quite the contrary, relative risk of low results obtained in 1 and 2 tests was lower in the test group, subgroup III, than in the same subgroup in the reference group 
Table 8

Comparative analysis of data obtained via "Number square" test among all the examined workers

\begin{tabular}{|l|c|c|c|}
\hline \multicolumn{1}{|c|}{ "Number square" test data } & $\begin{array}{c}\text { Test group, } \\
n=166\end{array}$ & $\begin{array}{c}\text { Reference group. } \\
n=33\end{array}$ & $\begin{array}{c}\text { Validity of differences } \\
\text { between groups, } p<0.05\end{array}$ \\
\hline Correct answers, number & $11(7 ; 13)$ & $13(10 ; 14)$ & 0.02 \\
\hline Mistakes, number & $7(5 ; 11)$ & $7(4 ; 9)$ & 0.11 \\
\hline \multicolumn{2}{|c|}{ Frequency of different attention levels, \% } \\
\hline Low attention (from 0 to 5 correct answers) & 19.3 & 12.1 & 0.33 \\
\hline
\end{tabular}

Table 9

Comparative analysis of data obtained via "Number square" test among workers with different working experience

\begin{tabular}{|c|c|c|c|c|c|c|c|c|c|}
\hline $\begin{array}{c}\text { 'Number square' } \\
\text { test data }\end{array}$ & $\begin{array}{c}\text { Test group, } \\
\text { subgroup I } \\
n=77 \\
\end{array}$ & $\begin{array}{c}\text { Test group, } \\
\text { subgroup II } \\
n=53\end{array}$ & $\begin{array}{c}\text { Test group, } \\
\text { subgroup III } \\
n=46\end{array}$ & $\begin{array}{c}\text { Ref.group, } \\
\text { subgroup I } \\
n=15 \\
\end{array}$ & $\begin{array}{c}\text { Ref.group, } \\
\text { subgroup II } \\
n=12 \\
\end{array}$ & $\begin{array}{c}\text { Ref.group, } \\
\text { subgroup III } \\
n=20 \\
\end{array}$ & $p^{1}$ & $p^{2}$ & $p^{3}$ \\
\hline $\begin{array}{l}\text { Correct answers, } \\
\text { number }\end{array}$ & $12(9 ; 14)$ & $11(8 ; 12)$ & $9(6 ; 11)$ & $13(11 ; 13)$ & $\begin{array}{c}13.5 \\
(10.5 ; 14.5)\end{array}$ & $10.5(7 ; 14)$ & 0.78 & 0.02 & 0.29 \\
\hline Mistakes, number & $7(5 ; 10)$ & $7(5 ; 11)$ & $8.5(6 ; 12)$ & $8(4 ; 10)$ & $5(2.5 ; 7)$ & $8(7 ; 10)$ & 0.91 & 0.029 & 0.95 \\
\hline \multicolumn{10}{|c|}{ Frequency of different attention levels, $\%$} \\
\hline $\begin{array}{l}\text { Lowe attention } \\
\text { (from } 0 \text { to } 5 \text { cor- } \\
\text { rect answers) }\end{array}$ & 16.9 & 18.9 & 23.9 & 13.3 & 8.3 & 16.7 & 0.73 & 0.38 & 0.69 \\
\hline $\begin{array}{l}\text { Standard attention } \\
\text { (more than } 5 \text { cor- } \\
\text { rect answers) }\end{array}$ & 83.1 & 81.1 & 76.1 & 86.7 & 91.7 & 83.3 & 0.73 & 0.38 & 0.69 \\
\hline
\end{tabular}

$\mathrm{N}$ o t e : $p^{1}$ is validity of differences between the test group, subgroup I, and the reference group, subgroup I; $p^{2}$ is validity of differences between the test group, subgroup II, and the reference group, subgroup II; $p^{3}$ is validity of differences between the test group, subgroup III, and the reference group, subgroup III.

and amounted to $R R=0.58(95 \%$ CI 0.29-1.20) and $R R=0.64(95 \%$ CI 0.16-2.61). However, results lower than standard levels in 3 and 4 tests were detected in $20.4 \%$ and $18.4 \%$ workers in this subgroup accordingly whereas there were no such workers in the reference group, subgroup III (Table 10).

Table 11 contains the results obtained via linear regression analysis of a probable deterioration in cognitive functions among oil and gas extraction operators depending on their working experience. We revealed statistically significant dependence between working experience under exposure to adverse occupational factors for oil and gas extraction operators and probable low results obtained via "Concepts exclusion" test $\left(b_{0}=13.46 ; b_{1}=-0.97\right.$; $\left.F=15.85 ; \quad R^{2}=0.071 ; \quad p=0.0001\right)$, "Image memory" test $\left(b_{0}=9.96 ; b_{1}=-0.13 ; F=36.78\right.$; $\left.R^{2}=0.151 ; p=0.0001\right)$, "Number memory" test $\left(b_{0}=7.75 ; b_{1}=-0.04 ; F=9.91 ; R^{2}=0.045\right.$; $p=0.002)$, "Number square" test $\left(b_{0}=11.03\right.$; $\left.b_{1}=-0.11 ; \quad F=9.95 ; R^{2}=0.057 ; p=0.002\right)$. We didn't detect any similar statistically significant dependence in the reference group.

Cognitive disorders become apparent via cognitive functions dropping lower than their standard levels; they can develop both due to natural ageing of a body and due to exposure to various occupational factors (noise, vibration, etc.). Effects produced by neurotoxicants on the nervous system become apparent via diffuse damage to the brain that is accompanied with occurring brainstem-hypothalamic syndrome, and syndrome related to cerebral and psychoneurological disorders ${ }^{2}$. Impacts exerted by adverse occupational factors (chemical factors, noise, vibration, and labor intensity) on cognitive functions have been examined by many authors [11, 17-19]. As per data obtained by M. Reale et al., 80 examined workers employed in oil extraction had increased anxiety levels and occupational stress signs [20]. However, research 
Table 10

Results obtained via neural-psychological tests that were lower than standard levels

\begin{tabular}{|c|c|c|c|}
\hline Tests & Test group, $n=209$ & Reference group, $n=44$ & $R R(C I 95 \%)$ \\
\hline \multicolumn{4}{|c|}{ Attributes in the test and reference groups } \\
\hline Absent, \% & $64(30.6)$ & $21(47.7)$ & $0.64(0.44-0.92)$ \\
\hline 1 test, $\%$ & $83(39.7)$ & $18(40.9)$ & $0.97(0.66-1.44)$ \\
\hline 2 tests, $\%$ & $39(18.7)$ & $4(9.1)$ & $2.05(0.77-5.45)$ \\
\hline 3 tests, $\%$ & $14(6.7)$ & $1(2.3)$ & $2.9(0.39-21.8)$ \\
\hline All 4 tests & $9(4.3)$ & 0 & - \\
\hline \multicolumn{4}{|c|}{ Attributes in subgroups I (99/20) } \\
\hline Absent, people (\%) & $35(35.4)$ & $12(60.0)$ & $0.59(0.37-0.92)$ \\
\hline 1 test, people (\%) & $37(37.4)$ & $6(30.0)$ & $1.12(0.55-2.26)$ \\
\hline 2 tests, people (\%) & $25(25.3)$ & $2(10.0)$ & $2.52(0.65-9.82)$ \\
\hline 3 tests, people $(\%)$ & $2(2.0)$ & 0 & - \\
\hline All 4 tests & 0 & 0 & - \\
\hline \multicolumn{4}{|c|}{ Attributes in subgroups II (61/15) } \\
\hline Absent, people (\%) & $22(36.1)$ & $7(46.7)$ & $0.77(0.41-1.46)$ \\
\hline 1 test, people (\%) & $30(49.2)$ & $7(46.7)$ & $1.05(0.58-1.92)$ \\
\hline 2 tests, people (\%) & $7(11.5)$ & 0 & - \\
\hline 3 tests, people $(\%)$ & $2(3.3)$ & $1(6.7)$ & $0.49(0.05-5.07)$ \\
\hline All 4 tests & 0 & 0 & - \\
\hline \multicolumn{4}{|c|}{ Attributes in subgroups III (49/9) } \\
\hline Absent, people (\%) & $7(14.3)$ & $2(22.2)$ & $0.64(0.16-2.61)$ \\
\hline 1 test, people (\%) & $16(32.7)$ & $5(55.6)$ & $0.58(0.29-1.20)$ \\
\hline 2 tests, people $(\%)$ & $7(14.3)$ & $2(22.2)$ & $0.64(0.16-2.61)$ \\
\hline 3 tests, people $(\%)$ & $10(20.4)$ & 0 & - \\
\hline All 4 tests & $9(18.4)$ & 0 & - \\
\hline
\end{tabular}

Table 11

"Working experience - cognitive functions parameters" liner regression: attributes

\begin{tabular}{|c|c|c|c|c|c|c|c|}
\hline $\begin{array}{l}\text { Exposure } \\
\text { marker }\end{array}$ & Effect marker & $\begin{array}{l}\text { A trend of a change } \\
\text { in parameters }\end{array}$ & $b_{0}$ & $b_{1}$ & $F$ & $R^{2}$ & $p$ \\
\hline \multicolumn{8}{|c|}{ Test group } \\
\hline \multirow{4}{*}{ 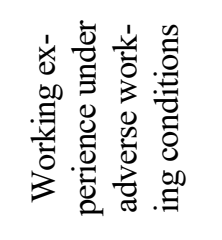 } & "Concepts exclusion" & Descending & 13.46 & -0.97 & 15.85 & 0.071 & 0.0001 \\
\hline & "Image memory" & Descending & 9.96 & -0.13 & 36.78 & 0.151 & 0.0001 \\
\hline & "Number memory" & Descending & 7.75 & -0.04 & 9.91 & 0.045 & 0.002 \\
\hline & "Number square" & Descending & 11.03 & -0.11 & 9.95 & 0.057 & 0.002 \\
\hline \multicolumn{8}{|c|}{ Reference group } \\
\hline \multirow{4}{*}{ 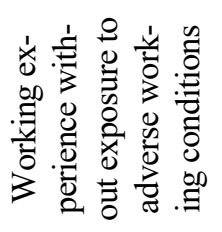 } & "Concepts exclusion" & Descending & 14.07 & -0.16 & 0.209 & 0.005 & 0.65 \\
\hline & "Image memory" & Descending & 10.32 & -0.041 & 0.592 & 0.014 & 0.45 \\
\hline & "Number memory" & Descending & 8.53 & -0.16 & 0.38 & 0.009 & 0.54 \\
\hline & "Number square" & Descending & 11.93 & -0.06 & 0.45 & 0.014 & 0.51 \\
\hline
\end{tabular}

performed by S.V. Tsyrempilov et al. didn't reveal any authentic deviations in cognitive functions among 56 workers who were occupationally exposed to neurotoxicants (aromatic hydrocarbons, toluene, and benzine) [21]; it may be due to selected diagnostic tests not being specific enough. To achieve relevant accuracy in research, O.I. Shevchenko et al. recommend applying several most informative diagnostic psychological tests simultaneously and these tests should be specific in terms of revealing damage done to specific brain structures by this or that neurotoxicant [22]. 
Our research results revealed that oil and gas extraction operators who had to work under exposure to several adverse occupational factors (chemicals and noise) had 1.3-1.6 times lower cognitive flexibility, image/number memory, and attention; lower memory capacity, attention, and analytical abilities were 2-3 times more frequent among them, and a risk of a decrease in synthetic and analytical activity was more than 5 times higher $(R R=5.55 ; 95 \% C I=1.4-21.9)$ than among workers with permissible working conditions at their workplaces. Results obtained via linear regression analysis revealed dependence between cognitive disorders occurrence in oil and gas extraction operators and their working experience under adverse working conditions; we didn't reveal any similar dependence in the reference group. A set of neural-psychological tests ("Concepts exclusion", "Image memory", "Number memory", and "Number square") was applied for assessing cognitive functions; the assessment revealed their availability, reproducibility and objectivity of their results even at early stages in cognitive dysfunction development (pre-dementia stage). It allows using these tests in periodical medical examinations for detecting people with minimal cognitive dysfunctions and further profound examinations, prevention activities, and finding solutions to issues detected due to medical inspections.

\section{Conclusions}

1. We detected authentic dependence between disorders in cognitive functions and dura- tion of working experience under exposure to adverse occupational factors (chemical factor and occupational noise) for oil and gas extraction operators. Their cognitive flexibility (synthetic and analytical activity), image and number memory capacity, and attention were 1.3-1.6 times lower than among workers who had permissible working conditions at their workplaces.

2. Oil and gas extraction operators had 5 times higher relative risk of cognitive disorders occurrence, and low memory capacity, attention, and analytical activity were 2-3 times more frequent among them than among workers from the reference group (permissible working conditions at workplaces).

3. Using a set of neural-psychological tests ("Concepts exclusion", "Image memory", "Number memory", and "Number square") during periodical medical examinations provided for oil and gas extraction operators allows diagnosing cognitive dysfunction already at an early stage (pre-dementia stage) in its development (when working experience already exceeds 10 years) and revealing people with its minimal signs for further prevention activities and finding solutions to issues detected due to medical inspections.

Funding. The research work was performed within The Basic Activity Plan approved by the Federal Scientific Center for Medical and Preventive Health Risk Management Technologies for 2020 .

Conflict of interests. The authors declare there is no any conflict of interests.

\section{References}

1. Perneczky R., Alexopoulos P., Schmid G., Sorg C., Förstl H., Diehl-Schmid J., Kurz A. Cognitive reserve and its relevance for the prevention and diagnostic of dementia. Nervenarzt, 2011, vol. 82, no. 3 , pp. 325-335. DOI: $10.1007 / \mathrm{s} 00115-010-3165-7$

2. Larrieu S., Letenneur L., Orgogozo J.M., Fabrigoule C., Amieva H., Le Carret N., Barberger-Gateau P., Dartigues J.F. Incidence and outcome of mild cognitive impairment in a population-based prospective cohort. Neurology, 2002, vol. 26, no. 59 (10), pp. 1594-1599. DOI: 10.1212/01.wnl.0000034176.07159.f8

3. Rodríguez-Sánchez E., Mora-Simón S., Patino-Alonso M.C., García-García R., EscribanoHernández A., García-Ortiz L., Perea-Bartolomé M.V., Gómez-Marcos M.A. Prevalence of cognitive impairment in individuals aged over 65 in an urban area: DERIVA study. BMC Neurology, 2011, vol. 17, no. 11 , pp. 147 . DOI: $10.1186 / 1471-2377-11-147$

4. Diagnostic and statistical manual of mental diseases. 5-th ed. (DSM-5, DSM-V). Washington, DC, London, American Psychiatric Association Publ., 2013, 970 p.

5. Damulin I.V., Ekusheva E.V. Dementia due to cerebral small vessel damage: current ideas on its pathogenesis and therapy. Nevrologiya, neiropsikhiatriya, psikhosomatika, 2014, no. 4, pp. 94-100 (in Russian). 
6. Mokhova Yu.A. The brain plasticity and neurographics. Russian Journal of Education and Psychology, 2019, vol. 10, no. 4, pp. 61-66 (in Russian).

7. Van Spronsen M., Hoogenraad C. Synapse pathology in psychiatric and neurologic disease. Curr. Neurol. Neurosci. Rep, 2010, vol. 10, no. 3, pp. 207-214. DOI: 10.1007/s11910-010-0104-8

8. Fjell A.M., Walhoyd K.B. Structural brain changes in aging: courses, causes and cognitive consequences. Rev. Neurosci, 2011, vol. 21, no. 3, pp. 187-221. DOI: 10.1515/revneuro.2010.21.3.187

9. Jessen F., Amariglio R.E., van Boxtel M., Breteler M., Ceccaldi M., Chételat G., Dubois B., Dufouil C. A conceptual framework for research on subjective cognitive decline in preclinical Alzheimer's disease. Alzheimers Dement, 2014, vol. 10, no. 6, pp. 844-852. DOI: 10.1016/j.jalz.2014.01.001

10. Timasheva G.V., Akhmetshina V.T., Repina E.F., Khafizova A.S. Assessment of the biological age of workers engaged in hazardous working conditions. Meditsina truda i ekologiya cheloveka, 2017, vol. 12, no. 4, pp. 52-58 (in Russian).

11. Sinyavskii Yu.A., Berdygaliev A.B. Characteristics of screening for cognitive impairments of employees of the lead processing enterprise. Nauka o zhizni i zdorov'e, 2018, no. 3, pp. 41-46 (in Russian).

12. Gimranova G.G., Bakirov A.B., Karimova L.K., Beigul N.A., Shaikhlislamova E.R. Factors and Indicators of Oil Extraction Occupational Risks. Vestnik Rossiiskogo gosudarstvennogo meditsinskogo universiteta, 2014, no. 1, pp. $72-75$ (in Russian).

13. Orudzhev R.A., Dzhafarova R.E. The peculiarities of the toxic effect of petroleum hydrocarbons on the human organism. Vestnik VGMU, 2017, vol. 16, no. 4, pp. 8-15 (in Russian).

14. Vishnevskaya N.L., Plakhova L.V., Polednyak P., Bernatik A. Evaluation of joint effect of factors of small intensity of production environment and labor process on work ability and error of action of operators of high-tech energy complexes. Vestnik Permskogo natsional'nogo issledovatel'skogo politekhnicheskogo universiteta. Geologiya. Neftegazovoe i gornoe delo, 2017, vol. 16, no. 2, pp. 183-190 (in Russian).

15. Wright B.A., Peters E.R., Ettinger U., Kuipers E., Kumari V. Moderators of noise-induced cognitive change in healthy adults. Noise Health, 2016, vol. 18, no. 82, pp. 117-132. DOI: 10.4103/1463-1741.181995

16. Blaginin A.A. Nadezhnost' professional'noi deyatel'nosti operatorov slozhnykh ergaticheskikh system [Reliability of occupational activities accomplished by operators dealing with complex ergative systems]. Sankt-Peterburg, Leningradskii gosudarstvennyi universitet im. A.S. Pushkina Publ., 2006, 144 p. (in Russian).

17. Prokopchuk N.N., Skrebtsova N.V., Popov V.V. State of cognitive functions in able-bodied men driving motor transport. Ekologiya cheloveka, 2013, no. 10, pp. 9-13 (in Russian).

18. Shevchenko O.I., Konstantinova T.N., Katamanova E.V., Brezhneva I.A. Some aspects of forming the psychoneurological disorders in exposure to mercury. Byulleten' Vostochno-Sibirskogo nauchnogo tsentra Sibirskogo otdeleniya Rossiiskoi akademii meditsinskikh nauk, 2008, vol. 5, no. 63, pp. 34-38 (in Russian).

19. Shevchenko O.I., Katamanova E.V., Lakhman O.L. Rates of biological aging and its relationship to neuropsychological peculiarities in patients with occupational neurointoxications. Ekologiya cheloveka, 2017, no. 3, pp. 10-14 (in Russian).

20. Reale M., Costantini E., D’Angelo C., Coppeta L., Mangifesta R., Jagarlapoodi S., Di Nicola M., Di Giampaolo L. Network between cytokines, cortisol and occupational stress in gas and oilfield workers. International journal of molecular sciences, 2020, vol. 21, no. 3, pp. 1118. DOI: 10.3390/ijms21031118

21. Tsyrempilov S.V., Budaeva S.Ts., Partilkhaeva A.L. Indices of functional state of central nervous system in conditions of chronic professional polyneurontoxication. Byulleten' VostochnoSibirskogo nauchnogo tsentra Sibirskogo otdeleniya Rossiiskoi Akademii Meditsinskikh Nauk, 2010, vol. 72, no. 2, pp. 121-123 (in Russian).

22. Shevchenko O.I., Lakhman O.L., Katamanova E.V., Mesheryagin V.A. The methods of psychological testing in diagnosis of early displays of occupational neurointoxication. Sibirskii meditsinskii zhurnal (Irkutsk), 2012, no. 6, pp. 79-83 (in Russian).

Savinkov M.A., Ustinova O.Yu., Nosov A.E., Ivashova Yu.A., Kostarev V.G. Risks related to cognitive disorders development in workers with different work experience employed at an oil extracting facility. Health Risk Analysis, 2021, no. 2, pp. 83-93. DOI: 10.21668/health.risk/2021.2.08.eng

Received: 02.02.2021

Accepted: 17.03 .2021

Published: 30.09 .2021 